\title{
Antibody studies in multiple sclerosis and experimental 'allergic' encephalomyelitis
}

\author{
E. A. CASPARY, E. J. FIELD, AND E. JANET BALL \\ From the Medical Research Council Research Group on Demyelinating Diseases, \\ the University and Royal Victoria Infirmary, Newcastle upon Tyne
}

Experimental 'allergic' encephalomyelitis produced in animals by the injection of whole brain or brain fractions with adjuvant is generally believed to be allergic in character (Kies and Alvord, 1959) and is considered by some authors a model for multiple sclerosis in man (Miller and Schapira, 1959). Attempts to correlate complement-fixing antibodies to brain components with the occurrence or severity of disease, either in animal experiments or in human neurological conditions, have not, however, been successful (Macleod, Ridley, Smith, and Field, 1962; Roberts, 1962; Melnick, 1963). Some positive findings might well be considered examples of the 'autoimmune complement fixation' factors demonstrated by Gajdusek (1958). On the other hand, skin sensitivity tests claimed to show a relationship with the onset and severity of experimental disease (Waksman and Morrison, 1951) have been negative when carried out with a preparation of purified encephalitogenic factor (Caspary and Field, 1963a). Moreover, patients with multiple sclerosis also failed to show any skin reaction with highly active brain fractions (Böhme, Paal, Kersten, and Kersten, 1963; Field, Caspary and Miller, 1963). It was, therefore, considered that an investigation of circulating antibodies to whole brain and other tissue suspensions by a method not involving complement fixation might afford further information as to the type of antibody present in multiple sclerosis and experimental allergic encephalomyelitis. Such information would appear especially relevant in view of the recent claims by Bornstein (1963) that some myelotoxic and gliotoxic factor(s) are present in such sera but perhaps do not fix complement (Paterson, 1963).

\section{METHODS}

Freshly separated sera from assured cases of multiple sclerosis, Hashimoto's disease, rheumatoid arthritis, and from medical students and nurses six to eight weeks after immunization with B.C.G. were tested. The clinical diagnosis of Hashimoto's disease and rheumatoid arthritis was confirmed in each case by independent serological tests.
Groups of about two dozen adult guinea-pigs (400 to $500 \mathrm{~g}$.) were injected intracutaneously on the dorsum of the foot with $0 \cdot 1 \mathrm{ml}$. of either $20 \% \mathrm{w} / \mathrm{v}$ whole human brain with Freund's complete adjuvant (Difco) $1: 2$ (encephalitogenic mixture) or the same volume of Freund's complete adjuvant alone.

Animals which developed experimental allergic encephalomyelitis from the injection of brain plus Freund's adjuvants were exsanguinated at the onset of the disease or 30 days after injection. Animals of the other group were similarly treated at the same times. The nervous system was examined histologically in each case.

Sera were inactivated at $56^{\circ} \mathrm{C}$. for half an hour. Those from guinea-pigs were absorbed with half their volume of human group $O$ Rhesus-positive washed and packed red blood cells at room temperature $\left(18^{\circ} \mathrm{C}\right.$.) for 20 minutes.

All sera were stored at $-20^{\circ} \mathrm{C}$.

\section{PREPARATION OF ANTIGENS}

Antigen suspensions of whole human and guinea-pig brain and human kidney were prepared as follows. The tissue was made up to $20 \%$ (wet weight) with $0.15 \mathrm{M}$ saline, macerated in a mechanical blender (M.S.E.) for five minutes and further dispersed in an all-glass grinder. One drop of $0.2 \%$ sodium azide was added to $20 \mathrm{ml}$. of suspension to inhibit possible bacterial growth before storage at $-20^{\circ} \mathrm{C}$.

Inactive brain fraction was a simple saline extract of whole human brain centrifuged at 16,000 r.p.m. for one hour at $4^{\circ} \mathrm{C}$. to remove all particulate matter, dialysed against $0.5 \mathrm{M}$ saline, and finally freeze-dried (Caspary and Field, 1963b). This fraction was virtually devoid of encephalitogenic activity.

Circulating antibody to brain suspensions and brain extract was determined by a slight modification of the bis-diazo-benzidine red cell methods of Stavitsky and Arquilla (1955) and Arbesman, Rose, Kantor, and Beede (1960). Human group O Rhesus-positive red cells taken into acid-citrate-dextrose medium (and not older than three weeks) were washed thrice with normal saline before use. Freshly prepared bis-diazo-benzidine was found to be essential for consistent results. When stored at $-20^{\circ} \mathrm{C}$. it could not be used for more than two weeks. Tissue antigens were diluted to give a concentration of $1 \%$ (wet weight) and dried brain extract made up at $1 \mathrm{mg} . / \mathrm{ml}$. (dry weight). Serial doubling dilutions of $0.25 \mathrm{ml}$. of 
serum were made in perspex trays (R. B. Turner Ltd.); to these were added $0.05 \mathrm{ml}$. of bis-diazo-benzidine red cells coated with antigen. Plates were gently rocked and allowed to stand for five to six hours at room temperature before reading. They were again read next morning.

In view of the long incubation times at room temperature, $0.0004 \%$ sodium azide was incorporated into the $1 \%$ rabbit serum-buffered saline mixture used as the diluent. Results were read by one observer (E.A.C.) who had established his own criteria. There was little, if any, difference between the short- and long-term readings, though on occasion the longer settling period gave a more 'clear-cut' appearance.

\section{RESULTS}

HUMAN DISEASE Titres have been recorded as numbers of wells positive, e.g., three means positive at a dilution of $1: 8$ (the first well being $1: 2$ ).

Brain and kidney suspensions were used as antigen. Results are set out in Table IA. It appears that whereas titre to brain is raised in multiple sclerosis (at the limit of statistical confidence), it is less so than in Hashimoto's disease, rheumatoid arthritis, and
B.C.G. immunization. On the other hand, in none of these conditions was there a significant titre against kidney; even the B.C.G.-inoculated subjects who showed highest anti-kidney titre did not differ significantly from normal.

Comparison of antibody titres to brain in the different clinical conditions is set out in Table IB, which shows that titres in multiple sclerosis are significantly lower than in Hashimoto's disease, rheumatoid arthritis, and B.C.G. immunization. On the other hand, Hashimoto's disease, rheumatoid arthritis, and B.C.G. immunization do not differ amongst themselves, though the last has the highest titre.

EXPERIMENTAL ALLERGIC ENCEPHALOMYELITIS Results are set out in Table II. It will be seen that in 8 experimental allergic encephalomyelitis there is a $\vec{\circ}$ significantly raised titre against human brain, guinea-pig brain, and human kidney, when the disease has been produced by inoculation of human brain (plus Freund's adjuvants). Moreover, there is no significant difference between the titres to the

TABLE IA

ANTIBODIES TO BRAIN AND KIDNEY SUSPENSIONS IN SERUM OF PATIENTS SUFFERING FROM MULTIPLE SCLEROSIS, HASHIMOTO'S DISEASE, OR RHEUMATOID ARTHRITIS, AND IN NORMAL INDIVIDUALS RECENTLY IMMUNIZED WITH B.C.G.

\begin{tabular}{|c|c|c|c|c|}
\hline & \multicolumn{4}{|l|}{ Antigens } \\
\hline & \multicolumn{2}{|l|}{ Brain } & \multicolumn{2}{|l|}{ Kidney } \\
\hline & Mean Titre & Significance (P value) & Mean Titre & Significance ( $P$ value) \\
\hline $\begin{array}{l}\text { Normal controls } \\
\text { Multiple sclerosis } \\
\text { Hashimoto's disease } \\
\text { Rheumatoid arthritis } \\
\text { B.C.G. immunization }\end{array}$ & $\begin{array}{l}0.50 \pm 0.75 \\
1.06 \pm 0.82 \\
1.75 \pm 1.60 \\
1.76 \pm 0.81 \\
2.63 \pm 2.28\end{array}$ & $\begin{array}{l}0.02-0.01 \\
0.001 \\
0.001 \\
0.001\end{array}$ & $\begin{array}{l}0.50 \pm 0.75 \\
0.70 \pm 0.74 \\
0.72 \pm 0.83 \\
0.63 \pm 0.86 \\
1.00 \pm 1.54\end{array}$ & $\begin{array}{l}0 \cdot 3-0 \cdot 2 \\
0 \cdot 3-0 \cdot 2 \\
0 \cdot 6-0 \cdot 5 \\
0 \cdot 2-0 \cdot 1\end{array}$ \\
\hline
\end{tabular}

TABLE IB

COMPARISON OF CIRCULATING ANTIBODY TITRES BETWEEN DISEASES

$\boldsymbol{A}$ $B$

Multiple sclerosis Multiple sclerosis Hashimoto's disease Multiple sclerosis Hashimoto's disease

$\begin{array}{ll}\text { Hashimoto's disease } & 0.02-0.05 \\ \text { Rheumatoid arthritis } & 0.02-0.05 \\ \text { Rheumatoid arthritis } & 0.9 \\ \text { B.C.G. immunization } & 0.01 \\ \text { B.C.G. immunization } & 0.2-0.1\end{array}$

TABLE II

CIRCULATING ANTIBODIES TO TISSUE SUSPENSIONS BY THE BIS-DIAZO-BENZIDINE METHOD

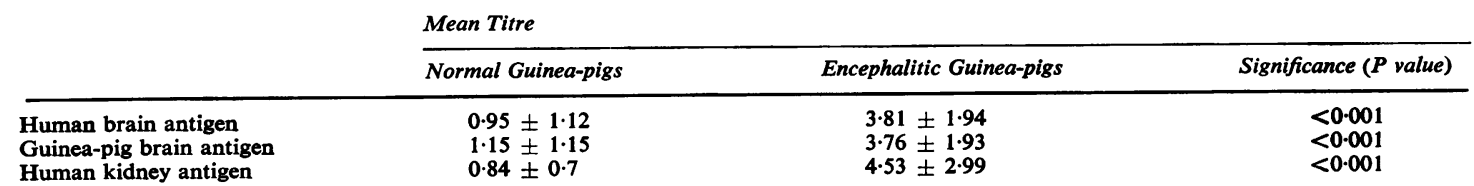

Comparison of titres between the antigens in encephalitic animals.

Human brain antigen with guinea-pig brain antigen $\ldots \ldots \ldots \ldots \ldots \ldots . P=0.9$

Human brain antigen with guinea-pig brain antigen $\ldots \ldots \ldots \ldots \ldots \ldots \ldots \ldots$
Human brain antigen with human kidney antigen $\ldots \ldots \ldots \ldots \ldots$ 
three antigens within either the group of normal animals or that with experimental allergic encephalomyelitis.

When a saline extract of human brain was used as antigen, results were as indicated in Table III. A group of nine animals immunized with Freund's complete adjuvant alone was included in this experiment as a control.

\section{TABLE III}

CIRCULATING ANTIBODIES TO INACTIVE SALINE EXTRACT OF BRAIN BY THE BIS-DIAZO-BENZIDINE METHOD

\begin{tabular}{lc} 
Mean Titre & $\begin{array}{l}\text { Significance } \\
(P \text { value })\end{array}$ \\
\hline $0.81 \pm 0.88$ & \\
$5.29 \pm 2.03$ & $<0.001$ \\
$5.11 \pm 3.14$ & $<0.001$
\end{tabular}

Encephalitic animals

Animals injected with Freund's

adjuvant alone

$<0.001$

Comparison of encephalitic animals with those immunized with Freund's adjuvant alone $\ldots \ldots \ldots \ldots \ldots \ldots \ldots \ldots \ldots \ldots . P=0.9$

In view of the variety of antigens shared by brain and kidney, both as suspensions and simple saline tissue extracts (Caspary, 1962; Caspary and Field, 1963b), a comparison of the responses to suspension and extract antigens was carried out. This showed no significant differences between the antibody response to whole brain antigen and brain extract $(P=0 \cdot 1)$ and whole kidney antigen and brain extract $(P=0.4)$ in animals developing experimental allergic encephalomyelitis.

\section{DISCUSSION}

Several previous attempts to demonstrate circulating antibody to tissue suspension in experimental allergic encephalomyelitis and multiple sclerosis by the double diffusion in agar technique (Ridley, 1962) or by the tanned red cell methods of Stavitsky (1954) and Boyden (1951) have not been successful. This may have been due to the binding of tissue suspensions to tanned red cells being weak and inconsistent, and is perhaps related to the lipid content of these suspensions. In our hands the bis-diazo-benzedrene method of Stavitsky and Arquilla (1955) has been the only technique giving reproducible and reliable results with human and animal tissue suspensions.

The response of guinea-pigs to whole brain immunization is characterized by greatly increased antibody production not only against brain suspension but also against a suspension of kidney. This agrees with the previous findings of Caspary (1962) and Caspary and Field (1963b) that the serum of rabbits immunized with an encephalitogenic mixture of whole brain and adjuvant producing experimental allergic encephalomyelitis contains antibody against liver, kidney, and muscle as well as against specific components of brain. The present results show that the response to injection of an encephalitogenic mixture of human provenance is not a general stimulation of 'anti-human' antibody, since the circulating antibodies are tissue- rather than speciesspecific, as shown by the markedly raised titres against guinea-pig brain suspension.

Experiments with a saline extract of brain demonstrate that antibody is formed mainly against soluble elements of the tissues, or perhaps against some subcellular component(s) remaining in colloidal suspension after disintegration and high speed centrifugation. There is, however, no direct relation between this extract and the experimental disease, since the extract is virtually non-encephalitogenic.

The production of antibodies to brain extract following the injection of Freund's adjuvant alone suggests some crossed antigen between the tubercle bacillus and brain tissue. Further evidence of this has been brought forward by Field, Caspary, and Ball (1963) from their examination of human sera. Relationship between the antigens of brain and the tubercle bacillus is also suggested by the observation that pretreatment with Freund's adjuvants affords substantial protection against subsequent challenge with an encephalitogenic mixture (Kies and Alvord, 1958). The position is further complicated by the observation that the role played by circulating antibody in the evolution of experimental allergic encephalomyelitis is still unsettled. Whilst it has not been possible to transfer the disease by the serum of a sick animal, it has been claimed that serum from an animal with experimental allergic encephalomyelitis will afford some measure of protection when given to guinea-pigs subsequently challenged with an actively encephalitogenic mixture (Vulpé, 1959; Paterson, 1963). The recent successful transfer by means of lymphocytic cells, albeit under rather special conditions (Paterson and Didakow, 1961), has suggested that a cellular rather than a humoral immune mechanism is at work in experimental allergic encephalomyelitis. However, recent demonstration of myelotoxic and gliotoxic activity of experimental allergic encephalomyelitis serum in tissue culture experiments has re-opened the question of a humoral cytopathogenic agent (Bornstein, 1963) and there is evidence, too, that this agent may differ from complement-fixing antibodies upon which so much attention has been fixed in the past (Paterson, 1963). In particular, it would be of considerable interest to know if the brain antibodies appearing after inoculation of Freund's adjuvants exhibited myelotoxic or gliotoxic properties in vitro.

So far as the results from human sera are concerned, there is no evidence of a non-specific reaction similar to that described by Gajdusek 
(1958) and Mackay and Gajdusek (1958). The agglutination method used in the present work does not involve complement and so differs fundamentally from Gajdusek's 'auto-immune complement fixation' test.

It is curious that diseases apparently differing so widely as Hashimoto's disease and rheumatoid arthritis should show antibodies to whole brain of approximately equal titres. An association between these two conditions has, however, been reported (Buchanan, Crooks, Alexander, Koutras, Wayne, and Gray, 1961; Hijmans. Doniach, Roitt, and Holborrow, 1961) but the significance of their both showing antibodies to brain (but not to kidney) is unexplained.

\section{SUMMARY}

In multiple sclerosis, antibodies to brain suspension are found but are not of such high titre as in Hashimoto's disease, rheumatoid arthritis, or after B.C.G. immunization.

Antibodies to human kidney are not found in these conditions.

In the serum of guinea-pigs with experimental allergic encephalomyelitis produced by injection of human brain with Freund's adjuvants antibody is present to human brain, guinea-pig brain, and human kidney.

Guinea-pigs injected with Freund's adjuvants alone produce antibodies to a non-encephalitogenic saline brain extract, as do animals with experimental allergic encephalomyelitis.

The antibodies in question in this work are demonstrated without the intervention of complement.

The significance of these findings is briefly discussed.
We should like to thank Dr. Henry Miller for access to patients from whom sera were obtained; Dr. S. G. Owen and Dr. Malcolm Thompson kindly supplied sera from cases of Hashimoto's disease and rheumatoid arthritis respectively.

This work was supported in part by the Multiple Sclerosis Society.

\section{REFERENCES}

Arbesman, C. E., Rose, N. R., Kantor, S. Z., and Beede, R. B. (1960) J. Allergy, 31, 317.

Böhme, D., Paal, G., Kersten, W., and Kersten, H. (1963). Nature (Lond.), 197, 609.

Bornstein, M. B. (1963). Symposium on Organ Culture, Washington, 1962. Nat. Cancer Inst. Monogr. No. 11, p. 197.

Boyden, S. V. (1951). J. exp. Med., 93, 107.

Buchanan, W. W., Crooks, J., Alexander, W. D., Koutras, D. A., Wayne, E. J., and Gray, K. G. (1961). Lancet, 1, 245.

Caspary, E. A. (1962). Biochem. J., 84, 47P.

$\longrightarrow$, and Field, E. J. (1963a). Nature (Lond.), 197, 1218

- (1963b). Dtsch. Z. Nervenheilk., 184, 478.

Field, E. J., Caspary, E. A., and Miller, H. G. (1963). Unpublished observations.

- -

Gajdusek, D. C. (1958). Arch. intern. Med., 101, 9.

Hijmans, W., Doniach, D., Roitt, I. M., and Holborrow, E. J. (1961) Brit, med. J., 2, 909.

Kies, M. W., and Alvord, E. C. Jr. (1958). Nature (Lond.), 182, 1106.

- - (ed.) (1959). "Allergic" Encephalomyelitis (Proc. Sympos ium). Thomas, Springfield, Illinois.

Mackay, I. R., and Gajdusek, D. C. (1958). Arch. intern. Med. 101무 30.

Macleod, I., Ridley, A. R., Smith, C., and Field, E. J. (1962). Bri med. J., 1,1525 .

Melnick, S. C. (1963). Ibid., 1, 368.

Miller, H., and Schapira, K. (1959). Ibid., 1, 737; 811.

Paterson, P. Y. (1963). Symposium on Organ Culture, Washington

1962. Nat. Cancer Inst. Monogr., No. 11, p. 212 .
, and Didakow, N. C. (1961). Proc. Soc. exp. Biol. (N.Y.), 108 768.

Ridley, A. R. (1962). Thesis for the degree of Ph.D., University of Durham.

Roberts, S. D. (1962). Lancet, 1, 164.

Stavitsky, A. B. (1954). J. Immunol., 72, 360.

-, and Arquilla, E. R. (1955). Ibid., 74, 306.

Vulpé, M. (1959). In "Allergic" Encephalomyelitis (Proc. Symposium), ed. M. W. Kies and E. C. Alvord, p. 457. Thomas, Springfield, Illinois.

Waksman, B. H., and Morrison, L. R. (1951). J. Immunol., 66, 421. 